СУЧАСНА СИСТЕМА МІЖНАРОДНОГО ПРАВА

УДК 341.33

\title{
PROTECTIONOF MEDICAL PERSONNELIN THE CONTEXT OF ARMED CONFLICT IN UKRAINE
}

\author{
ПРОБЛЕМИ ЗАХИСТУ МЕДИЧНОГО ПЕРСОНАЛУ В \\ КОНТЕКСТІ ЗБРОЙНОГО КОНФЛІКТУ В УКРАЇНІ
}

\section{ПРОБЛЕМЫ ЗАЩИТЫ МЕДИЦИНСКОГО ПЕРСОНАЛА В КОНТЕКСТЕ ВООРУЖЕННОГО КОНФЛИКТА В УКРАИНЕ}

\section{Medvedieva M. O.}

Doctor of Juridical Sciences, Professor of the International Law Chair at the Institute of International Relations of Taras Shevchenko National University of Kyiv. E-mail: medvedieva.maryna@gmail.com

\section{Habrelian H. V.}

PhD student, Institute of Internationa IRelations of Taras Shevchenko Nationa lUniversity of Kyiv. Email: gabrelyangoar@gmail.com

\author{
Медведсва М. О. \\ Доктор юридичних наук, професор, професор кафедри міжнародного права \\ ІнститутуміжнароднихвідносинКиївськогонаціональногоуніверситетуімені Тараса Шевченка. Е-mail: \\ medvedieva.maryna@gmail.com
}

\section{Габрелян Г. В.}

Аспірантка Інституту міжнародних відносин Київського національного університету імені Тараса Шевченка. Еmail: gabrelyangoar@gmail.com

\section{Габрелян Г. В.}

Аспирантк Института международных отношений Киевского национального университета имени Тараса Шевченко. E-mail: gabrelyangoar@gmail.com

\section{Медведева М. А.}

Доктор юридических наук, профессор, профессоркафедрымеждународного права Института международных отношений Киевского национального университета имени Тараса Шевченко. Е-mail: medvedieva.maryna@gmail.com

\section{Габрелян Г. В.}

Аспирантк Института международных отношений Киевского национального университета имени Тараса Шевченко. E-mail: gabrelyangoar@gmail.com

Abstract. It has been proved that since the beginning of the Russian aggression in the east of Ukraine the problems of international humanitarian law, in particular the protection of medical personnel in the context of armed conflict, have become particularly relevant. It is determined that, through its peaceful policy, Ukraine is not ready for armed aggression. The provisions of international normative legal acts regulating the protection of medical personnel and medical facilities during armed conflicts of international and non-international character are examined. The basics of implementation of the provisions of international humanitarian law by national 
legislation and peculiarities of criminal responsibility for violations and crimes against physicians in the area of armed conflict are investigated.

Keywords: armed conflicts, armed conflict in Ukraine, medical personnel, the right to health, international humanitarian law, international human rights law, the rights and responsibilities of healthcare professionals.

Анотація. Доведено, щуо від початку російської агресії на Сході України проблеми міжнародного гуманітарного права, зокрема захисту медичного персоналу в умовах збройного конфлікту, набули особливої актуальності. Визначається, щзо через свою миролюбиву політику Украӥна виявилась не готовою до збройної агресії. Вивчено положення міжнародних нормативно-правових актів, якими регулюється захист медччного персоналу та медичних об'єктів під час збройних конфліктів міжнародного та неміжнародного характеру. Досліджені особливості імплементачії положень міжнародного гуманітарного права в національномуправі та особливості кримінальної відповідальності за порушення та злочини проти медиків у зоні збройного конфлікту.

Ключові слова:збройні конфлікти, збройний конфлікт в Украӥні, медичний персонал, право на здоров'я, міжнародне гуманітарне право, міжнародне право прав людини, права та обов'язки медичних прачівників.

Аннотация. Доказано, что от начала российской агрессии на востоке Украинь проблемы международного гуманитарного права, в частности защчиты медицинского персонала в условиях вооруженного конфликта, приобрели особую актуальность. Определяется, что из-за своей миролюбивой политики Украина оказалась не готовой $к$ вооруженной агрессии. Изучены положения международных нормативно-правовых актов, регулирующих защиту медицинского персонала и медичинских объектов во время вооруженных конфликтов международного и немеждународного характера. Исследованы особенности имплементаци иположений международного гуманитарного права 6 национальном праве $и$ особенности уголовной ответственности за нарушение $u$ преступления против медиков в зоне вооруженного конфликта.

Ключевые слова: вооруженные конфликты, вооруженный конфликт в Украине, медицинский персонал, право на здоровье, международное гуманитарное право, международное право прав человека, права и обязанности медицинских работников.

Research problem setting. Despite the titanic efforts of human rights defenders, the situation with the protection of medical personnel in armed conflicts has not been improved in recent years. In particular, according to statistics provided by the Safeguarding Health in Conflict coalition, in 2018 in the world 167 health workers were killed, 710 health workers were injured, 173 medical facilities were attacked or destroyed, 111 medical transport units were damaged or destroyed [14]. These data indicate a total violation of international humanitarian law (hereinafter IHL) and international human rights law.

In Ukraine, after the onset of the armed conflict in the east, accompanied by the attacks by the Russian mercenaries and regular troops, the situation with the protection of medical personnel has deteriorated. Ukraine is the only European country included into the list of countries with the highest number of violations of international humanitarian law. In particular, in 2018, by indicators of attacks on medical personnel, medical facilities and medical transport, Ukraine outperformed such countries as Burkina Faso, Myanmar, Sudan and Somalia and has the same rates as Pakistan concerning the number of incidents of IHL violations [14].According to the World Health Organization data for 2017, 'Since the start of the conflict, at least 160 health facilities have been shelled on both sides of the contact line, while some 130 facilities remain either partially or fully nonoperational. Over 400 health facilities in these conflict areas in Ukraine report insufficient stocks of medicines' [15]. Safeguarding Health in Conflict coalition provides some other data for 
2018: number of attacks on healthcare was 11, number of healthcare workers killed - 2, number of healthcare workers injured -7 , number of health facilities damaged or destroyed -2 [14].Such figures indicate that the problem of medical personnel's protection in the armed conflict in Ukraine is urgent and needs quick and effective reaction at the international as well as national scale.

The purpose of the article. The purpose of the article is to investigate the problems of the protection of medical personnel in the context of the armed conflict in Ukraine and to identify promising directions of legal mechanisms for protection of medical personnel in emergency situations.

Analysis of the latest researches and publications. The above-mentioned problems in the context of international humanitarian law have been explored by such foreign scholars as Baxter P.P., Blunchli I., de Vattel E., Gasser H.P., Gefter A.V., Grotius G., David E., Gentili A., Kalshoven F., Lieber F., Marteny G.F., Muagne G., Oppenheim L., Picte J., dePre J., Remacle R., Suarez F., Ferdross A., Hyde C. Among Ukrainian scientists who wrote on the issues of IHL and international human rights law, including in the context of protection of victims of war, it is possible to distinguish the works of Antypenko V.F, Gnatovsky M.M., Gutnik V.V., Korotky T.R. However, it can be stated that the issues of protection of medical personnel in the context of armed conflict in Ukraineremain unexplored in domestic scientific literature, despite their relevance and importance.

Basic research material.The provision of medical assistance in armed conflict (international or non-international) is the basis for the realization of the fundamental human right to health which is enshrined in many international treaties, such as the Constitution of the World Health Organization of 1946 (preamble), the International Covenant on Economic, Social and Cultural Rights of 1966 (article 12), Convention on the Rights of the Child of 1989 (article 24), and other international instruments, such as the Universal Declaration on Human Rights of 1948 (article 25). Medical personnel in the context of armed conflict have certain privileges;special distinctive signsand worldwide recognized emblems are used to protect them. The ensurance of the rights of medical personnel in armed conflict is based on customary, treaty legal rules as well as recommendations of international organizations.

IHL prohibits attacks on medical personnel and medical transport without any exceptions. This prohibition is embodied in the four Geneva Conventions of 12 August 1949 [1-3] and the Additional Protocols thereto of 8 June 1977 [4-5], as well as IHL customary rules. This prohibition is effective both in an international and non-international armed conflict. The rules of IHL vary depending on the nature of the conflict (whether international or non-international) and protected groups: medical personnel and sanitation units that are part of the armed forces, in accordance with the rules of the Geneva Convention for the Amelioration of the Condition of the Wounded and Sick in Armed Forces in the Field of 12 August 1949 (hereinafter - Geneva Convention I) and the Geneva Convention for the Amelioration of the Condition of Wounded, Sick and Shipwrecked Members of Armed Forces at Sea of 12 August 1949, or civilian medical personnel and civilian medical units in accordance with the provisions of the Geneva Convention Relative to the Protection of Civilian Persons in Time of War of 12 August 1949. But theuniversal prohibitionof attacks on medical personnel and medical transportremains unchanged.Medical personnel and healthcare units have a higher level of protection than civilians and civil objects. Healthcare workers cannot be targeted, they cannot be intimidated, and they are not allowed to be threatened. Both sides of the conflict must support medical personnel and provide the conditions under which they can perform their functions.

Civilian medical personnel shall be respected and protected during international and noninternationalarmed conflicts, and shall be granted all available help for the performance of their dutiesin accordance with Article 15 of the Protocol Additional to the Geneva Conventions of 12 August 1949, and Relating to the Protection of Victims of International Armed Conflicts, of 8 June 1977 (hereinafter - the Additional Protocol I) and Article 9 of the Protocol Additional to the Geneva Conventions of 12 August 1949, and Relating to the Protection of Victims of NonInternational Armed Conflicts, of 8 June 1977 (hereinafter - the Additional Protocol II).To facilitate 
the identification of medical personnel in an area of an international armed conflict with a view to granting the necessary protection, a specialidentity cardmust be issued in accordance with Annex I to the Additional Protocol I.

Some of these important guarantees for medical personnel are repeated by the International Committee of the Red Cross (hereinafter - ICRC) in its study on Customary International Humanitarian Law (hereinafter - Customary IHL) of 2005, namely Rule 25 [Henckaerts, 2005: 79]. The work by ICRC is 'the most comprehensive compilation of legislative and regulatory measures, along with expressions of opinio juris, available in this field' [13, para.7].Though there is a remarkable progress in codifying international humanitarian law, the ICRC believes that its study presents an accurate assessmentof the current state of customary international humanitarian law [Henckaerts, 2005: xvi, xvii].

Medical personnel shall not be compelled to carry out tasks which are not compatible with their humanitarian mission (Article 15(3) of the Additional Protocol I and Article 9(1) of the Additional Protocol II). Persons engaged in medical activities shall neither be compelled to perform acts or to carry out work contrary to, nor be compelled to refrain from acts required by, the rules of medical ethics (Article 16(2) of the Additional Protocol I and Article 10(2) of the Additional Protocol II). Under no circumstances shall any person be punished for having carried out medical activities compatible with medical ethics (Article 16(1) of the Additional Protocol I, Article 10(1) of the Additional Protocol II, Rule 26 of the Customary IHL).Paragraph 3 of the Article 16 of the Additional Protocol I and para. 4 of the Article 10 of the Additional Protocol II stipulate that during armed conflict medical secrecy must be ensured, medical personnel shall not disclose patients' information. Meanwhile, medical personnel lose their protection if they commit, outside their humanitarian function, acts harmful to the enemy (Rules 25, 28 and 29 of the Customary IHL).

Medical units enjoy respect and protection at all times and cannot be the object of attack. Stationary and mobile medical units cannot under any circumstances be attackedon the contrary, the parties to the conflict are obliged to protect them, in accordance with Article 19 of the Geneva Convention I, Article 12 of the Additional Protocol I and Article 11 Additional Protocol II. Under Article 35 of the Geneva Convention I, transports of wounded and sick or of medical equipment shall be respected and protected in the same way as mobile medical units. The special protection granted to medical units shall cease if and when the civilian medical units are used to commit, outside their humanitarian function, acts harmful to the enemy (Article 13(2) of the Additional Protocol I). At the same time, IHL allows the medical personnel to have light individual weapons for their own defense or for that of the wounded and sick in their charge (Article 13(2) and Article 28(3) of the Additional Protocol I).Attacks directed against medical personnel and objects displaying the distinctive emblems of the Geneva Conventions in conformity with international law are prohibited (Rule 30 of the Customary IHL).

In 2011, in its resolution 'Health Care in Danger: Respecting and Protecting Health Care' the ICRC recalled to the states their obligations to respect and protect the health-care personnel and facilities in times of armed conflict or other emergencies, urged all states to adopt domestic implementation measures based on relevant international legal obligations, called on states to ensure that their armed forces and security forces implement all applicable international legal obligations in relation to armed conflict, including situations of occupation, with regard to protection for the health-care services, including through the development and adoption of appropriate doctrine, procedures, guidelines and training, to ensure effective investigation and prosecution of crimes committed against health care personnel [11].

Referring to Ukrainian experience, we should stress that while all above-mentioned IHL treaties have been ratified by Ukraine, national legislation does not provide comprehensive legal mechanisms for the protection of medical personnel and medical facilities. This problem is particularly acute for physicians who are risking their own lives, performing their duties and saving the lives of Ukrainian soldiers at the conflict-affected areas of Donetskand Luhansk regions where Joint Operations of Ukrainian forces (formerly Antiterrorist Operation) are going on in order to repel the Russian aggression. In 2018, there were 11 attacks on healthcare workers and healthcare 
facilities in Ukraine. In these 11 incidents, two physicians were killed, seven were injured, three were threatened and three drivers were injured. Two medical facilities were damaged and four were forcibly closed [14].

Outcrying were the violations of international humanitarian law, which guarantees the protection of medical personnel, in the fighting near Debaltsevo in 2015. In particular, on February 9, 2015, a military surgeon was unable to take a seriously injured person out of the battlefield for nine hours because a Russian tank blocked the road and didn't let a sanitary vehicle to move. On the same day, whole brigade of military doctors (SergiyKatsabin, AnatoliySulima and MykhailoBalyuk) were killed by the direct hit of the shell. They were traveling in a sanitary reanimation car, which had all the necessary distinctive emblems, and it was impossible to mix it with a military vehicle [16]. In 2019, a nurse who assisted civilians during the attack by the Russian mercenaries was killed [20]. No one has been punished at this time.

Though Ukraine and Russia which are parties to the armed conflict are parties to the Geneva Conventions, Additional Protocols I and II, such examples witness that they do not comply with their obligations. The Russian Federation doesn't comply with its obligation to respect and protect the health-care personnel and facilities in times of armed conflict, and Ukraine doesn't comply with its obligation to adopt domestic implementation measures based on relevant international legal obligations and to ensure effective investigation and prosecution of crimes committed against medical personnel.

The violation of the prohibition of attacks on medical personnel or transport during armed conflict amounts to grave breaches of the Geneva Conventions. Acts described as grave breaches in the Conventions are grave breachesof theAdditional Protocol I if committed against those medical personnel, medicalunits or medical transports which are under the control of the adverseparty and are protected by this Protocol (Article 85 of the Additional Protocol I).Article 49 of the Geneva Convention I, Article 129 of the Geneva Convention II and Article 146 Geneva Convention IV stipulate that the High Contracting Parties undertake to enact any legislation necessary to provide effective penal sanctions for persons committing, or ordering to be committed, any of the grave breaches of the Conventions and are obliged to search for persons alleged to have committed, or to have ordered to be committed, such grave breaches, and shall bring such persons, regardless of their nationality, before its own courts. Parties to the conflict have to repressgrave breaches of the Conventions or of this Protocol which results from afailure to act when under a duty to do so (Article 86 of the Additional Protocol I).

Attacks on medical personnel and units during armed conflict are regarded as war crimes under national and international criminal law.Namely, Article 438 of the Criminal Code of Ukraine stipulates that violations of the laws and customs of war provided for by international treaties ratified by the Verkhovna Rada of Ukraine are crimes under Ukrainian criminal law [7]. Article 8(2)of the Rome Statute of the International Criminal Court (hereinafter - ICC)envisages that intentionally directing attacks against medical units and transport, and personnel using the distinctive emblems of the Geneva Conventions are regarded as serious violations of the laws and customs applicable in international and non-international armed conflicts[6].

In its Reports on Preliminary Examination Activities in Ukraine (2018 and 2019) the ICC Office of the Prosecutor while defining the jurisdiction rationemateriaeof the ICC stressed that the 'use of heavy weapons by all parties to the conflict not only led to numerous casualties and injuries resulting from severe injuries, but also to large-scale damage and destruction of ... hospitals and other medical institutions, ... both in government-controlled territory and in areas controlled by armed groups' [21, para. 84;12, para. 275]. The Office of the Prosecutor referred tointentional attacks against protected objects, such as medical institutions, among the alleged war crimes in accordance with Article 8(2)(b)(ix) or Article 8(2)(e)(iv) of the Rome Statute in its Report of 2018 (para. 86). The application of these articles depends on the qualification of the armed conflict in Ukraine, either it is international or non-international, or both. Besides, para. 87 of the Report of 2018 refers to intentionally directing attacks against buildings, material, medical units and transport, and personnel using the distinctive emblems of the Geneva Conventions. For example, the shelling 
of a Ukrainian ambulance car, which took place on July 1, 2019 and resulted in the death of Ukrainian military medical personnel [17], may be qualified as a war crime under Article 8 of the Rome Statute of the International Criminal Court.

Many medical workers have been disabled during the Joint Operations of Ukrainian forces as a result of wounds or other health injuries emanating from explosions in the areas in which they perform their duties and in settlements located directly on the line of war hostilities.However, according to national Ukrainian legislation, it is impossible to grant the status of 'a participant in hostilities' for such medical workers, which would provide them with a number of social benefits guaranteed by the Law of Ukraine 'On the status of war veterans and guarantees of their social protection' of 1993. It is impossible because such a status directly contradicts Articles 43-44 of the Additional Protocol I. Healthcare personnel do not belong to combatants. Ukraine ratified this treaty, thus, recognized it as a part of national law being binding for the Ukrainian state.

Let's consider the key means of implementation of international humanitarian law at the national level in Ukraine. As already noted, Article 438 of the Criminal Code of Ukraine covers violations of treaties on international humanitarian law ratified by Ukraine [7]. However, this Article is not specific enough, it does not have the same list of grave breaches of Geneva Conventions and its Protocols as these treaties and the Rome Statute do stipulate. Thus, it lacks certainty for the effective prosecution of IHL violations. Meanwhile, there are several draft laws amending the Ukrainian Criminal Code in relation to war crimes. For example, draft law No. 9438 'On Amendments to Some Legislative Acts of Ukraine on Ensuring Harmonization of Criminal Law with the Provisions of International Law' supplements the Criminal Code with a war crime against humanitarian operations and protected emblems - intentional attacks in connection with an international armed conflict or a non-international armed conflict against medical facilities, personnel or transport that, in accordance with the rules of international humanitarian law, use the emblems established by the Geneva Conventions of 12 August 1949 [18]. Draft law No. 2689 'On Amendments to Some Legislative Acts of Ukraine on the Implementation of International Criminal and Humanitarian Law' defines the protected persons as, inter alia, medical personnel and prohibits any attacks thereon [19].

The Guidelines on the Application of International Humanitarian Law in the Armed Forces of Ukraine(2017) provide further explanations, details and clarity as to what constitutes a disciplinary or criminal offense with regard to non-compliance with a special protection of medical personnel and units. In particular, it specifies that objects which are under the IHL protection are medical units, sanitary vehicles, and hospitals; persons who are under the IHL protection are medical personnel (belonging to the Ukrainian Armed Forces as well as to the Ukrainian Red Cross Society) who are regarded as non-combatants [8]. The adversary's medical personnel are respected and protected and cannot be attacked unless engaged in hostile actions.Medical personnel shall be granted all available help for the performance of their duties. Any reprisals against protected objects and medical personnel are prohibited. The Guidelines stipulate that attacks on medical units and vehicles that have proper emblems and signals (although the absence of emblems does not imply the lack of protection afforded to such objects but complicates their identification) are regarded as prohibited methods of warfare.Grave breaches of IHL directed against protected persons are war crimes.

Thus, the Guidelines implemented main provisions of the IHL treaties, but we are of the opinion that for their proper enforcement it is necesssary to adopt specific national law, e.g. amendments to the Criminal Code mentioned above. The Guidelines approved by the order of the Ministry of Defense of Ukraine are not enough: only a strict legislative framework with criminal penalties mayensure effective investigation and prosecution of crimes committed against health care personnel during armed conflicts. As was previously stated, the Geneva Conventions stipulate that the states enact any legislation necessary to provide effective penal sanctions for persons committing the grave breaches of the Conventions. The ICRC commentary to these provisions supports our conclusion [10]. 
International governmental and non-governmental organizations paid a special attention to the protection of healthcare workers and facilities in armed conflict and adopted a set of recommendations with this regard. In particular, the United Nations General Assembly adopted resolution 37/194 'Principles of Medical Ethics relevant to the Role of Health Personnel, particularly Physicians, in the Protection of Prisoners and Detainees against Torture and Other Cruel, Inhuman or Degrading Treatment or Punishment'. The Council of Europe adopted resolution 904 (1988) 'On the protection of the humanitarian medical missions'. WHO adopted Resolution WHA46.39 'Health and Medical Services in Times of Armed Conflict' and resolution WHA55.13 'Protectionof Medical Missions during Armed Conflict'. NATO has adopted directive MC 326/2 'NATO Principles and Policies of Operational Medical Support'.

Conclusions.It has been revealed that due to its long-standing peaceful state policy, Ukraine was not ready for the considerable number of problems that arose from the armed aggression of the Russian Federation in Donbas. It is determined that the pressing need to study IHL as a tool to regulate military personnel's actions and ensure their protection has become particularly acute. The legal protection of medical personnel in armed conflict is directly related to the functions it performs, namely providing healthcare services. The provision of health care in armed conflict is linked to the enforcement ofhuman right to health. Healthcare workers are given certain privileges in armed conflict, and distinctive emblems and symbols are used to protect them. International legal protection for healthcare personnel in armed conflict is ensured by treaty, customary rules as well as recommendations of international organizations. It can be stated that the international legal protection of healthcare personnel, medical facilities and units in the context of armed conflict is clearly defined by international treaties and 'soft law' instruments, they envisage all necessary measures for the real protection of medical personnel and, consequently, victims of armed conflict.

Though Ukraine and Russia which are parties to the armed conflict are parties to the Geneva Conventions, Additional Protocols I and II, instances of killing or injuring the medical personnel as well as damaging medical units and facilities witness that they do not comply with their obligations. The Russian Federation doesn't comply with its obligation to respect and protect adversary's health-care personnel and facilities in times of armed conflict, and Ukraine doesn't comply with its obligation to adopt domestic implementation measures based on relevant international legal obligations and to ensure effective investigation and prosecution of crimes committed against medical personnel. While all above-mentioned IHL treaties have been ratified by Ukraine, national legislation does not provide comprehensive legal mechanisms for the protection of medical personnel and medical facilities.

Attacks on medical personnel and units during armed conflict are regarded as war crimes under national criminal law. Article 438 of the Criminal Code covers violations of treaties on international humanitarian law ratified by Ukraine. However, this Article is not specific enough, it does not have the same list of grave breaches of Geneva Conventions and its Protocols as these treaties and the Rome Statute do stipulate. Thus, it lacks certainty for the effective prosecution of IHL violations.Some secondary legal acts of Ukraine, like the order of the Ministry of Defense of Ukraine on the application of international humanitarian law in the Armed Forces of Ukraine,implemented main provisions of the IHL treaties, but for the proper enforcement of the latter it is necesssary to adopt specific national law, includingrelevant amendments to the Criminal Code. Only a strict legislative framework with criminal penalties may ensure effective investigation and prosecution of crimes committed against health care personnel during armed conflicts.

\section{References:}

1. GenevaConvention (I)for the Amelioration of the Condition of the Wounded and Sick in Armed Forces in the Field of 12 August 1949. <https://ihldatabases.icrc.org/ihl/7c4d08d9b287a42141256739003e636b/fe20c3d903ce27e3c125641e004a92f3 $>$. 
2. GenevaConvention (II) for the Amelioration of the Condition of Wounded, Sick and Shipwrecked Members of Armed Forces at Sea of 12 August 1949. <https://ihldatabases.icrc.org/applic/ihl/ihl.nsf/Treaty.xsp?documentId=2F5AA9B07AB61934C12563CD002 D6B25\&action=openDocument>.

3. Geneva Convention (IV) Relative to the Protection of Civilian Persons in Time of War of 12 August

$<$ https://ihldatabases.icrc.org/applic/ihl/ihl.nsf/Treaty.xsp?documentId=AE2D398352C5B028C12563CD002D 6B5C\&action=openDocument $>$.

4. Protocol Additional to the Geneva Conventions of 12 August 1949, and Relating to the Protection of Victims of International Armed Conflicts of 8 June $1977 .<$ https://ihldatabases.icrc.org/applic/ihl/ihl.nsf/Treaty.xsp?documentId=D9E6B6264D7723C3C12563CD002D 6CE4\&action=openDocument $>$.

5. Protocol Additional to the Geneva Conventions of 12 August 1949, and Relating to the Protection of Victims of Non-International Armed Conflicts of 8 June 1977. <https://ihldatabases.icrc.org/applic/ihl/ihl.nsf/Treaty.xsp?documentId=AA0C5BCBAB5C4A85C12563CD00 2D6D09\&action=openDocument $>$.

6. Rome Statuteof the International Criminal Court of 17 July 1998. <https://www.icccpi.int/resource-library/documents/rs-eng.pdf > .

7. Кримінальний кодекс України (2001). Відомості Верховної Ради України. № 25-26. Ст.131.

8. Наказ Міністерства оборони України № 164 «Про затвердження Інструкції про порядок виконання норм міжнародного гуманітарного права у Збройних Силах України» від 23.03.2017[TheGuidelinesontheApplicationofInternationalHumanitarianLawintheArmedForcesofU kraine]. <https://zakon.rada.gov.ua/laws/show/z0704-17>.

9. HenckaertsJ. M., Doswald-BeckL. (2005) 'CustomaryInternationalHumanitarianLaw: VolIRules'. Cambridge University Press.

10. International Committee of the Red Cross (1952) 'CommentarytheGenevaConventionfor the Amelioration of the Condition of the Wounded and Sick in Armed Forces in the Field'. <https://ihldatabases.icrc.org/applic/ihl/ihl.nsf/Comment.xsp?action=openDocument\&documentId=F2D40BE D87D146D1C12563CD0042232B>.

11. International Committee of the Red Cross (2011) 'Resolution 5 'HealthCareinDanger: RespectingandProtectingHealthCare'.

$<$ https://www.icrc.org/en/doc/resources/documents/resolution/31-international-conferenceresolution-5-2011.htm>.

12. International Criminal Court (2019)'Report on Preliminary Examination Activities'. $<$ https://www.icc-cpi.int/itemsDocuments/191205-rep-otp-PE.pdf $>$.

13. International Law Commission of the United Nations (2015) 'Second Report on the Protection of the Environment in Relation to Armed Conflicts Submitted by Marie G. Jacobsson, Special Rapporteur'. UN Doc A/CN.4/685.

14. SafeguardingHealthinConflictCoalition (2018) 'ImpunityRemains: AttacksonHealthCarein 23 CountriesinConflict'.

$<$ https://www.safeguardinghealth.org/sites/shcc/files/SHCC2019final.pdf>.

15. World Health Organization Regional Office for Europe (2017) 'World humanitarian day: WHO urges more health aid to address Ukraine's humanitarian crisis'.<http://www.euro.who.int/en/countries/ukraine/news/news/2017/08/world-humanitarian-daywho-urges-more-health-aid-to-address-ukraines-humanitarian-crisis>.

16. Вижив, бо хотів “Фанти”. Історія хірурга і пацієнта 3 Дебальцівського котла [HesurvivedbecausehewantedthePhantas.

ThehistoryofthesurgeonandthepatientfromtheDebaltsevoBoiler].

$<$ https://www.bbc.com/ukrainian/features-51549971>.

17. Обстріл санітарного автомобіля ЗСУ на Донбасі: двоє загиблих [TheshellingofanambulancecaroftheArmedForcesinDonbas: twodead]. 
$<\mathrm{https://www.dw.com/uk/обстріл-санітарного-автомобіля-зсу-на-донбасі-двоє-загиблих/а-}$ 49431162>.

18. Проект Закону про внесення змін до деяких законодавчих актів України щодо забезпечення гармонізації кримінального законодавства з положеннями міжнародного права [Draftlaw

'OnAmendmentstoSomeLegislativeActsofUkraineonEnsuringHarmonizationofCriminalLawwiththe ProvisionsofInternationalLaw]. <http://w1.c1.rada.gov.ua/pls/zweb2/webproc4_1?pf3511=65266>.

19. Проект Закону про внесення змін до деяких законодавчих актів України щодо імплементації норм міжнародного кримінального та гуманітарного права [Draftlaw 'OnAmendmentstoSomeLegislativeActsofUkraineontheImplementationofInternationalCriminaland HumanitarianLaw]. <http://w1.c1.rada.gov.ua/pls/zweb2/webproc4_1?pf3511=67804>.

20. У зоні АТО внаслідок ворожого обстрілу під час допомоги населенню загинула медсестра [Intheanti-terroristoperationzone, а resultofhostileshellingwhileassistingthepopulation]. <https://www.unian.ua/war/10015397-u-zoniato-vnaslidok-vorozhogo-obstrilu-pid-chas-dopomogi-naselennyu-zaginula-medsestra.html> .

21. Международный уголовный суд (2018) 'Отчет о действиях по предварительному расследованию' [International Criminal Court 'Report on Preliminary Examination Activities']. $<$ https://www.icc-cpi.int/itemsDocuments/2018-otp-rep-PE-Ukraine.pdf>. 